УДК 373.5.06:373.5.048

DOI:

Григорій Коссак, кандидат педагогічних наук, доцент кафедри біологї та хімї Дрогобицького державного педагогічного університету імені Івана Франка

Микола Шпек, кандидат сільськогосподарських наук, доцент кафедри біологї та хімії Дрогобииького державного педагогічного університету імені Івана Франка

Інеса Дрозд, кандидат сільськогосподарських наук, доцент кафедри біології та хіміі Дрогобицького державного педагогічного університету імені Івана Франка

\title{
ВПЛИВ НАЙБЛИЖЧОГО ОТОЧЕННЯ УЧНІВ НА РЕАЛІЗАЦЮЮ ПОДАЛЬШИХ ЖИТТЕВИХ ПЛАНІВ ТА ВИБІР ПРОФІЛЬНОГО РІВНЯ НАВЧАННЯ
}

У статті проаналізовано вплив найближчого оточення учнів на вибір профільного рівня навчання у закладах загальної середньої освіти, як засобу реалізачї окреслених життєвих планів. У процесі досліджень визначено, щуо більшість учнів самостійно здійснили вибір навчання у ліцеї відповідно до подальшої стратегії вступу до закладу вищої освіти. Встановлено, щуо серед впливів мікросоціуму на учня, найбільш вагомішими є поради батьків. Досліджено, чи відбулася корекція життєвих планів десятикласників після завершення периого семестру навчання.

Ключові слова: життеві плани; профільний рівень навчання; мікросочіум; соціальні чинники; самореалізація; самовизначення; сенс життя.

Jim. 7.

Grigorii Kossak, Ph.D.(Pedagogy), Associate Professor of the Biology and Chemistry Department, Drohobych Ivan Franko State Pedagogical University Mykola Shpek, Ph.D.(Agriculture), Associate Professor of the Biology and Chemistry Department,

Drohobych Ivan Franko State Pedagogical University

Inessa Drozd, Ph.D.(Agriculture), Associate Professor of the Biology and Chemistry Department, Drohobych Ivan Franko State Pedagogical University

\section{INFLUENCE OF STUDENTS' IMMEDIATE ENVIRONMENT ON THE IMPLEMENTATION OF FURTHER LIFE PLANS AND THE CHOICE OFTHE PROFILE LEVEL OF EDUCATION}

The article considers the influence of students' immediate environment on the choice of profile level of education in general secondary education institutions as a means for implementing further life plans. We consider the micro-society as the closest environment of the student-family, teachers, and friends, classmates, who have certain influences on the formation, self-determination and self-realization of the young person.

The study found that most students considered themselves independent, determined and confident, which influenced the choice of further education, although they do not deny a certain influence of parents on decisionmaking.

Note that the decision-making of students was also influenced by the unwillingness to make changes in their lives, to break the established relations in the micro-society.

Analysis of the students' motivation to continue specialized education in the lyceum showed that a third of respondents do not reject the importance of the educational process for self-development, self-improvement, opportunities for self-affirmation and self-realization, although it does not deny its purely practical importance, in particular, for achieving material well-being and obtaining a prestigious, well-paid profession.

At the same time, most respondents see hard work as a way to succeed in life, but do not reject the importance of financial resources as an additional guarantee to continue their studies on a contract basis.

It was found that most respondents were not disappointed in their choice of profile level of education and therefore feel comfortable in the educational institution, receive positive emotions in the learning process and from interpersonal communication. Students who have erred in their choices, who have had their life plans adjusted after the first semester and have changed their views on further education, perceive the educational process as a routine necessity and feel a certain frustration with the learning process.

Keywords: life plans; profile level of education; microcommunity; social factors; self-realization; personal identity; meaning of life.

$\Pi$ остановка проблеми. Підготовка учнів до подальшого життя, їх самовизначення та самореалізація вимагає від молодих людей сформованих моральних якостей, ціннісних орієнтацій, значної активності, реалізації власних нахилів, здібностей 


\section{ВПЛИВ НАЙБЛИЖЧОГО ОТОЧЕННЯ УЧНІВ НА РЕАЛІЗАЦІЮ ПОДАЛЬШИХ ЖИТТЕВИХПЛАНІВ ТА ВИБІР ПРОФІЛЬНОГО РІВНЯ НАВЧАННЯ}

та бажань. Саме тому проблеми подальшого свідомого вибору навчання, зокрема, профільного $€$ актуальною і має практичне значення для самореалізації у соціумі.

Адже, як зазначено у Законі України "Про освіту”, здобувачі освіти мають право на індивідуальну освітню траєкторію, що реалізується, зокрема, через вільний вибір видів, форм і темпу здобуття освіти, закладів освіти і запропонованих ними освітніх програм, навчальних дисциплін та рівня їх складності, методів і засобів навчання [3].

Цю статтю наведено також у Законі України “Про повну загальну середню освіту", де зазначається, що молодій людині надаються усі можливості для реалізації творчого потенціалу як невід'ємних складників становлення особистості [4].

Тому, відповідно до нахилів, уподобань, бажань, можливості самоствердитися, учні можуть вибрати один із запропонованих профільних рівнів навчання у старшій школі, що дасть змогу більш поглиблено засвоїти певні навчальні дисципліни або продовжити навчання у 3BO I-II рівня акредитації та отримати поряд із повною загальною середньою освітою ще й спеціальність з обраного фаху. Поряд з цим поглиблене вивчення профільних предметів допоможе учням більш грунтовно підготуватися до зовнішнього незалежного оцінювання

Адже основна мета профільного навчання передбачає створення умов для якісної освіти старшокласників відповідно до їхніх індивідуальних нахилів, можливостей, здібностей і потреб, забезпечення професійної орієнтації учнів на майбутню діяльність, створення можливостей для постійного духовного самовдосконалення особистості, формування інтелектуального та культурного потенціалу як найвищої цінності нації [5].

Наше дослідження було спрямоване на вивчення суб'єктивних впливів на учнів у процесі вибору профільного рівня навчання у старшій школі, визначення основних чинників, що вплинули на них, зокрема, можливості подальшого навчання в обраному закладі вищої освіти, досягнути успіху у житті чи займатися іншою справою.

У цьому контексті залишається актуальним визначення впливів дальнього чи ближнього оточення на вибір учнів, а саме, впливу батьків, педагогів, товаришів як класу так і позанавчального оточення, інтернет-ресурсів, зокрема, спілкування через соціальні мережі та огляд різноманітних сайтів.
Таким чином, дослідження суб'єктивних та об'єктивних чинників, що вливають на вибір спрямованості навчання учнів дає змогу грунтовніше визначити мотиви і шляхи реалізації потенційних можливостей учнів у освітньому процесі, основу яких закладено при навчанні як у початковій, так середній ланці та можливості регулювати, удосконалювати, розширювати набуті компетентності.

Аналіз основних досліджень та публікацій. На основі аналізу публікацій вітчизняних учених можна зазначити, що можливість самовизначення, самореалізації, самоствердження учнів буде успішною за умови свідомого вибору подальшого життєвого шляху, тобто досягнення окреслених планів, адже життєвий план - не тільки кінцевий результат, але й спосіб досягнення визначеної життєвої мети (Д. Дубравська, I. Зязюн, I. Кон, I. Мартинюк, Т. Титаренко та інші). Проблема постійного пошуку, визначення власної позиції в житті, прийняття та оцінка наслідків прийнятого рішення отримали обгрунтування у низці наукових праць учених: Б. Ананьєва, Л. Божович, С. Ісаєва, Н. Непомнящої А. Петровського, К. Платонова, В. Слободчикова та інших. У працях низки дослідників (Л. Божович, І. Кон, Г. Костюк) саме старший шкільний або ранній юнацький вік (1415-18років) розглядають як період соціального самовизначення учнів, вибору професійного й морального шляху та безпосередній вплив мікросоціуму - сім’ї і домашнього осередку, ровесників (А. Мудрик).

Проблему професійного вибору учнів та факторів, які стимулюють тягу до одержання вищої освіти, висвітлено у працях Д. Закатнова [2]; вплив сім'ї та ровесників - I. Зайченко [1]; у студіях низки науковців йдеться про пошук сенсу життя, розвиток життєвої компетентності,що створює для індивіда можливості гідної людської самореалізації в сучасному проблемному соціумі [7] та ін.

Метою статті $є$ проаналізувати вплив найближчого оточення учнів на свідомий вибір профільного рівня навчання та реалізацію подальших життєвих планів.

Виклад основного матеріалу. Дослідження проводились серед учнів Дрогобицького ліцею, що завершували навчання у дев'ятих класах, та упродовж першого семестру у десятих класах профільного рівня навчання у 2020 та напочатку $2021 \mathrm{p}$

У процесі дослідження визначалися вплив соціальних чинників найближчого оточення учня на стратегію вибору подальшого навчання, можливості самоствердитися, самореалізуватися 
в освітньому процесі та можливості реалізувати окреслені життєві плани.

В основу дослідження було покладене припущення, що стратегія суб'єктивного вибору подальшого продовження навчання формується в учня унаслідок впливу його найближчого оточення, тобто мікросоціуму, компоненти якого виступають вагомими та достатніми чинниками впливу на подальші життєві плани молодої людини, а процес їх реалізації є визначальним при оволодінні знаннями, уміннями і навичками у профільному навчанні.

На основі педагогічних досліджень, мікросоціум розглядається, як найближче середовище, що оточує учня, - сім'я, друзі, близькі, товариші, приятелі, сусіди, однокласники i $\epsilon$ визначальним для нього та у якому відбувається його становлення, соціальний та особистісний розвиток, формування індивідуальних рис, притаманних певному віковому періоді розвитку [6].

Причому кожна з окреслених груп соціуму має неоднаковий вплив на формування особистісних поглядів та переконань молодої людини. Завдяки системному впливу відбуваються формування, трансформація, переосмислення чи закріплення в учня особистісних цінностей орієнтацій, формування соціальної позиції та організація відповідно до неї поведінки, самоствердження у соціумі, що також впливає на можливість подальшого навчання учня у закладах освіти.

Слід зазначити, що сьогодні педагогічний колектив та профорієнтаційні групи ЗВО I-IV рівнів акредитації практично не впливають на професійну орієнтацію учнів. Це пов'язано з тим, що вибір подальшого освітнього закладу покладено на класного керівника і зводиться в основному до скерування учнів на подальше продовження навчання у їхньому освітньому закладі, профорієнтації закладів вищої освіти I-II рівнів акредитації проводяться епізодично, що, як правило, не повністю усвідомлюється учнями і переважно не впливає на їх вибір.

Важливо зазначити, що на становлення молодої людини, на формування їі поглядів, переконань значною мірою впливають інтернетресурси, а саме соціальні мережі, де вони проводять значний час та які частково впливають на їх особистісний вибір, накреслення подальших життєвих планів.

У процесі дослідження, 3 допомогою анкетування, ми визначали низку суб'єктивних чинників, що впливали на вибір учнів, а саме: їх ставлення до подальшого навчання, вибору закладу освіти після закінчення дев'ятого класу і впливу соціуму на цей вибір та результати аналізу власного вибору після завершення першого семестру у процесі корекції подальших життєвих планів.

Таким чином, аналіз об'єктивних й суб'єктивних впливів на формування життєвих планів та стратегію подальшого вибору освітнього закладу як можливості реалізувати власні схильності і бажання визначили напрям нашого дослідження.

Як показали наші дослідження, на розвиток певного когнітивного рівня пізнання, що склався у свідомості учнів в результаті їх розвитку, становлення, формування характеру, власних спостережень й аналізу навколишнього їх середовища, значною мірою впливають чинники найближчого оточення учнів (батьки, друзі), сам освітній процес, а відповідно - певною мірою вплив педагогів і однокласників та соціальних мереж, що проявляється на поведінковому рівні учнів.

Було визначено мотиви процесу оволодіння знаннями, уміннями та навиками, здобуття певних компетентностей, що формують зміст їхніх ціннісних уявлень, мотивів, прагнень та спрямованості учнів на подальше продовження навчання у закладах вищої освіти.

Слід зазначити, що значна частина респондентів (51\%) після завершення дев'ятого класу вирішили продовжити навчання у ЗВО I-II рівня акредитації, тобто отримати ступінь молодшого спеціаліста у коледжах, училищах, технікумах та, крім повної середньої освіти, певну професію. Мотиваційним чинником такого вибору також $є$ можливість продовжити навчання та отримати ступінь бакалавр за скороченим терміном навчання.

Інші респонденти (49 \%) продовжили навчання та обрали бажані для них профільні рівні у старшій школі. Із врахуванням учнів, що влилися з інших закладів загальної середньої освіти (32,8%), кількість старшокласників у порівнянні 3 дев'ятикласниками складала $73 \%$, тобто $27 \%$ учнів вибрали заклади професійної освіти.

Досліджуючи мотивацію учнів на продовження навчання у ліцеї, третина респондентів не відкидають значення освітнього процесу для власного саморозвитку, самовдосконалення, можливості до самоствердження та самореалізації, хоча і не заперечує чисто практичне його значення, як, наприклад, засіб отримання надалі вищої освіти $(48,4$ \%), досягнення певного успіху та матеріального добробуту у подальшому житті, здобуття престижної та добре оплачуваної професії $(39,1 \%)$. 


\section{ВПЛИВ НАЙБЛИЖЧОГО ОТОЧЕННЯ УЧНІВ НА РЕАЛІЗАЦІЮПОДАЛЬШИХ ЖИТТЕВИХПЛАНІВ ТА ВИБІР ПРОФІЛЬНОГО РІВНЯ НАВЧАННЯ}

Більшість респондентів уважають, що тільки досягнувши успіху, матеріального добробуту і тільки фінансова незалежність дасть можливість займатися благодійністю, тому зовсім незначна кількість респондентів бажали б допомагати іншим уже сьогодні, займатися громадською або благодійною діяльністю (17,0 \%), хоча для цього самостійно нічого не роблять, мотивуючи різними причинами, зокрема, зайнятістю у процесі навчання та відсутністю часу, не знають де можна займатися благодійністю.

При цьому, значна частина респондентів свій вільний час проводять переглядаючи телепередачі та в інтернеті (50 \%), 25 \% - у колі друзів і тільки 14,1 \% додатково опрацьовують навчальний матеріал, поглиблюючи свої знання.

Аналіз впливу мікросоціуму на побудову життєвих планів та свідомий вибір профільного рівня навчання показав, що значна частина респондентів загалом самостійно здійснили свій вибір (88,5 \%), хоча не заперечують певного впливу батьків (39,7\%). Певною мірою на прийняття рішення вплинуло бажання відтермінувати кардинальні зміни, що пов'язані 3 подальшим навчанням, тобто учні відчувають деяке занепокоєння, наявне відчуття невпевненості у можливості внесення нових змін у своє життя, порушенні встановлених відносин у мікросоціумі (37,5\%).

При цьому, значна частина респондентів вважають себе самостійними, рішучими та впевненими в собі (64,7 \%) і тільки 7,9\% респондентів відчувають себе дещо пригніченими і залежними від інших людей.

Слід зазначити, що більшість опитаних (70 \%) почувають себе комфортно у освітньому закладі, отримують позитивні емоції у процесі навчання та від спілкування з однокласниками й вчителями, хоча 18,8 \% сприймають процес навчання як рутинну необхідність для продовження отримання освіти у подальшому, а 11,2 \% відчувають певні неприємні емоції від процесу навчання.

Це пояснюється тим, що більшість респондентів $(77,5 \%)$ не розчарувалися у власному виборі профільного рівня навчання, 3,7 \% взагалі не задумувалися над цим, хоча у певної частини 3 них (14,6 \%) певною мірою відбулася корекція життєвих планів, змінилися погляди на подальше отримання освіти, а частина - (4,2 \%) змінили свої погляди і відчувають розчарування від обраного профілю та бажали б навчатися у закладах вищої освіти I-II рівня акредитації.

Шляхом досягнення поставленої мети значна частина респондентів вбачає наполегливу працю $(56,7 \%)$, а третина опитаних планують продовжити навчання у ЗВО тільки на контрактній основі (при наявності коштів на оплату за навчання), мотивуючи тим, що відбувається постійне скорочення бюджетних місць й відчувають сумнів у можливості конкурувати 3 іншими абітурієнтами, хоча $8,3 \%$ респондентів не відкидають виникнення сприятливої ситуації для них або щасливого випадку, що допоможе у реалізації окреслених планів.

Отже, більшість респондентів самостійно здійснили вибір профільного навчання, вбачаючи подальше навчання як засіб отримати вищу освіту, можливість саморозвитку, самовдосконалення та самореалізації і не відчувають розчарування від власного вибору, тому у процесі навчання відбувають себе комфортно, отримуючи задоволення від освітнього процесу та міжособистісного спілкування.

Висновки та перспективи подальших досліджень. Результати проведеного дослідження засвідчили, що більшість респондентів уважають себе самостійними, рішучими та впевненими у собі і зазначають, що самостійно обрали подальше навчання, хоча не заперечують певного впливу батьків на прийняття рішення. Респонденти мотивують подальше навчання як засіб саморозвитку, самовдосконалення, самоствердження та самореалізації, не заперечуючи подальше навчання для отримання вищої освіти та досягнення матеріального добробуту, здобуття престижної професії. Більшість опитаних не розчарувалися у виборі профільного рівня навчання, тому почувають себе комфортно в освітньому закладі, отримують позитивні емоції від спілкування та навчання, а частина визнали помилковим свій вибір, у них відбулася корекція життєвих планів, змінилися погляди на подальше отримання освіти, тому вони відчувають розчарування та незадоволення. Досягнення успіху у житті більшість респондентів вбачають у наполегливій праці, прицьому, не відкидають значення фінансових ресурсів як додаткової гарантії продовжити навчання. Розглянуте у статті питання $є$ актуальним у процесі реформування загальної середньої освіти і передбачає подальші дослідження.

\section{ЛIТЕРАТУРА}

1. Зайченко І. В. Педагогіка: підручник. 3-тє видання, перероблене та доповнене. Київ: Видавництво Ліра-К, $2016.608 \mathrm{c}$

2. Закатнов Д. О. Технології підготовки учнівської молоді до професійного самовизначення: монографія. Київ: Педагогічна думка, 2012. 160 с. VIII. 
4. Закон України "Про повну загальну середню освіту”. м. Київ 16 січня 2020 року № 463-IX.

5. Про затвердження Концепції профільного навчання у старшій школі. Наказ МОН № 1456 від 21.10.13 року.

6. Психологічний словник/Авт.-уклад. В.В.Синявський, О. П. Сергєєнкова/ За ред. Н. А. Побірченко. Київ, "Вища школа", 2000. 420 c.

7. Цінність життя підлітка: світоглядні орієнтири : Монографія. В. М. Шахрай (Ред.), Т. Ф. Алєксєєнко, Л. В. Гончар, Л. В. Канішевська, Р. В. Малиношевський (2019). Київ, 2019. 136 с.

\section{REFERENCES}

1. Zaichenko, I.V. (2016). Pedahohika: pidruchnyk [Pedagogy: textbook]. 3rd edition, revised and supplemented. Kyiv, 608 p. [in Ukrainian].

2. Zakatnov, D.O. (2012). Tekhnolohii pidhotovky uchnivskoi molodi do profesiinoho samovyznachennia: monohrafiia [Technologies of preparing students youth for professional self-determination: monograph]. Kyiv, $160 \mathrm{p}$. [in Ukrainian].
3. Zakon Ukrainy "Pro osvitu” vid 05.09.2017 № 2145VIII. [Law of Ukraine "On Education" dated 05.09.2017 No.2145-VIII]. [in Ukrainian].

4. Zakon Ukrainy "Pro povnu zahalnu seredniu osvitu". m. Kyiv 16 sichnia 2020 roku № 463-IX. [Law of Ukraine "On the Complete General Secondary Education" Kyiv dated 16.01.2020 No. 463-IX]. [in Ukrainian].

5. Pro zatverdzhennia Kontseptsii profilnoho navchannia u starshii shkoli [On approval of the Concept of subject oriented instruction in high school]. Order of the Ministry of Education and Science No. 1456 dated 21.10.13[in Ukrainian].

6. Psykholohichnyi slovnyk (2000). [Psychological dictionary]. Author.ed. V.V. Syniavskyi, O.P. Serhieienkova. (Ed.). N.A. Pobirchenko. Kyiv, 420 p. [in Ukrainian].

7. Tsinnist zhyttia pidlitka: svitohliadni oriientyry : Monohrafiia (2019). [Values of adolescent life: worldview landmarks: Monograph]. V. M. Shakhrai (Ed.), T.F. Alekseenko, L.V. Honchar, L.V. Kanishevska, R.V. Malinoshevsky. Kyiv, 136 p. [in Ukrainian].

Стаття надійшла до редакції 04.02.2021

УДК 378.091.21.:629.7

DOI:

Яна Нечепорук, кандидат педагогічних наук, докторант кафедри педагогіки та менеджменту освіти Центральноукраӥнського державного педагогічного університету імені Володимира Винниченка

\section{ОСНОВНІ ПРИНЦИПИ ВИКЛАДАННЯ ІНОЗЕМНОЇ МОВИ В АВІАЦИЙНИХ ЗАКЛАДАХ ОСВІТИ (середина ХХ ст. - початок XXI ст.)}

У статті автор розглядає основні приниипи викладання іноземної мови в авіаційній освіті із середини XX ст. до теперішнього часу. Стаття аналізуе зміни методів викладання іноземних мов у технічних освітніх закладах залежно від цілей $i$ задач, які ставила перед ними держава. В історії розвитку намої краӥни були періоди, коли вивчення іноземних мов мало непріоритетний характер. 50-ті рр. відзначалися використанням граматико-перекладного методу як в загальноосвітніх, так $і$ у вищих школах СРСР. 60-ті рр. та тогочасні реформи у сфері вивчення іноземних мов виявили певні недоліки попередників і наполягали на вивченні мови, використовуючи прямий метод, тобто уникаючи процесу перекладу під час навчання, намагатись не використовувати рідну мову. У 70-80-ті рр. підкреслювалась практична спрямованість методів викладання іноземної мови в льотних закладах освіти. Наразі, враховуючи стандартизацію та вимоги до сучасного авіаційного фахівия, в льотних навчальних закладах використовують велику кількість сучасних методів, щуо забезпечують активне володіння майбутніми авіаційними спеціалістами іноземною мовою як засобом формування і формулювання думок у галузі повсякденного спілкування та в галузі професійної діяльності.

Ключові слова: іншомовна підготовка; авіачійний навчальний заклад; історичні періоди.

Jim. 6.

Yana Necheporuk, Ph.D.(Pedagogy), Doctoral Itudent of the Pedagogy and Education Management Department,

Volodymyr Vynnychenko Central Ukrainian State Pedagogical University

\section{BASIC PRINCIPLES OF FOREIGN LANGUAGE TEACHING IN AVIATION EDUCATIONAL INSTITUTIONS (middle of the XX century - beginning of the XXI century) \\ In recent years, interest in mastering a foreign language (mainly English) grew significantly. With the development of mass media, especially Internet network, professional vocational becomes more affordable. Despite the necessity for a need and conscious motivation in English language mastering, most graduates of higher education institutions are not able to use it in their professional activities. That is why more and more attention is paid to the}

